\title{
Pathogenesis-Related Proteins in Grape
}

\author{
Shinichi Enoki and Shunji Suzuki
}

Additional information is available at the end of the chapter

http://dx.doi.org/10.5772/64873

\begin{abstract}
An overview of major pathogens and their control, plant defense mechanisms, and pathogenesis-related (PR) proteins and their roles in pathogen control is presented herein. Vitis vinifera, including wine grape and table grape, is one of the most valuable horticultural crops in the world because of its commercial use. However, V. vinifera cultivars are extremely susceptible to pathogens, particularly fungi and oomycetes, such as Botrytis cinerea and Plasmopara viticola, respectively. Plants have various defense mechanisms to counter these pathogens. One example is induced resistance, which involves the induction of the immune system in the event of a pathogen attack, including the generation of PR proteins. Some PR proteins possess antimicrobial activity. PR proteins are classified into 17 families, some of which are found in grape. Thus, their roles in grape have been actively studied. A new strategy to increase plant resistance to pathogens has been developed. A good understanding of grape defense mechanism through PR proteins is expected to open new doors to improve grape quality and yield by efficiently controlling pathogens in the future.
\end{abstract}

Keywords: pathogen, plant defense mechanism, induced resistance, pathogenesisrelated (PR) protein, pathogen control

\section{Introduction}

Vitis vinifera is one of the most important grape species for wine making. However, it is extremely susceptible to such pathogens as fungi and oomycetes. An understanding of grape defense mechanism is important because infection by pathogens leads to marked loss of fruit quality and yield.

Higher plants possess a variety of defense mechanisms against pathogens. Pathogenesisrelated $(\mathrm{PR})$ proteins are induced in response to infection by pathogens. PR proteins are 
classified into 17 families according to molecular structure and enzyme activity. The functions of all the families have not been reported in grape.

In this chapter, we review PR proteins in $V$. vinifera by presenting an overview of the latest knowledge of PR proteins in grape.

\section{Major pathogens and their control in grapevine}

Grapevine pathogens are roughly divided into fungi, bacteria, virus, and others. V. vinifera cultivars in particular are extremely susceptible to diseases caused by fungi and oomycetes, which result in huge economic losses worldwide. Of those diseases, the most prevalent are powdery mildew, gray mould, and downy mildew. Their characteristics, the resistance of grapevine to these diseases, and pathogen control in grapevine are described below.

\subsection{Major pathogens}

\subsubsection{Powdery mildew}

Powdery mildew caused by ascomycete Uncinula necator (syn. Erysiphe necator) is one of the most well-known fungal diseases in viticulture. In recent years, the decline of the effects of chemical fungicides and the emergence of climate suitable for fungal growth have led to the development of powdery mildew epidemic in European vineyards [1]. The symptoms are white powdery spots on the entire grapevine. Infected berries become brown and crack, resulting in loss of yield and seriously altering wine quality. Most V. vinifera cultivars are susceptible to $U$. necator, although some Vitis species show various levels of resistance [1-3].

\subsubsection{Gray mould}

Gray mould caused by ascomycete Botrytis cinerea is the major fungal disease in humid and temperate regions of the world [4]. B. cinerea invades a variety of agricultural crops and has a broad host range. In grape, the symptoms appear as 'gray mould' on the lesioned part of infected leaves, flower clusters, and ripening grape berries. $B$. cinerea infection likely occurs at all stages of grape growth. The development of gray mould in ripening berries results in loss of yield and berry quality.

\subsubsection{Downy mildew}

Downy mildew is caused by oomycete Plasmopara viticola. It is one of the most harmful diseases in grape grown in Europe and in the US [5]. Downy mildew appears as oily yellow spots on the surface of infected leaves. Loss of yield and lowered berry quality occur due to weakening of young shoot and death of leaf tissue. Boso et al. [6] investigated the susceptibility of V. vinifera cultivars and other Vitis species to downy mildew. V. vinifera 'Cabernet Sauvignon' was the least susceptible, whereas non-vinifera cultivars did not show symptoms of downy mildew in the field. 


\subsection{Pathogen control by chemical fungicide}

The above diseases caused by ascomycete and oomycete are generally controlled by spraying chemical fungicides, such as quinone outside inhibiting (QoI) fungicides, in the vineyard. QoI fungicides, which act by inhibiting fungal mitochondrial respiration, is one of the most widely used agents against pathogens in viticulture. However, in addition to the adverse effects of these fungicides, the emergence of fungi resistant to these fungicides has been reported [7, 8]. Therefore, restrictions and laws for use have been set by individual countries. The resistance of $P$. viticola to QoI fungicide is acquired by G143A mutation in cytochrome $\mathrm{b}$ that constitutes mitochondrial electron transport chain complex III [8, 9].

\section{Plant defense mechanism}

Plant defense mechanism is roughly classified into two categories: constitutive (static) resistance and induced (active) resistance (Table 1).

\begin{tabular}{|c|c|c|c|}
\hline \multicolumn{2}{|c|}{ Category } & Feature & Reference \\
\hline \multicolumn{4}{|c|}{ Constitutive (static) resistance [resistance inherent in plants] } \\
\hline \multirow{2}{*}{\multicolumn{2}{|c|}{ Physical resistance }} & Thickness and hardness of cell wall & [10] \\
\hline & & Hydrophobic environment created by cuticle layer & \\
\hline \multicolumn{2}{|c|}{ Chemical resistance } & Antimicrobial substances, such as phenol and saponin & [11] \\
\hline \multicolumn{4}{|c|}{ Induced (active) resistance [resistance newly induced by pathogen attack] } \\
\hline 1 & Formation of papilla & Physical and chemical barrier against penetration & [12] \\
\hline & Hardening of cell wall & Lignification & [13] \\
\hline & & Crosslinked polymers with glycoprotein & \\
\hline \multirow[t]{2}{*}{3} & Hypersensitive reaction & Containment of pathogen by autocide activity of cells & {$[14]$} \\
\hline & & Generation of ROS & \\
\hline 4 & Production of phytoalexins & Low molecular weight antimicrobial substance & [15] \\
\hline 5 & Production of PR proteins & With antimicrobial activity & [16] \\
\hline
\end{tabular}

Table 1. Categories of plant defense mechanisms against pathogens.

Constitutive resistance is a prophylactic resistance mechanism inherent in plants and is divided into physical resistance and chemical resistance. The former is the first barrier against pathogens created by the cell wall. The latter is realized by antimicrobial substances present in plants, such as polyphenols.

On the other hand, induced resistance involves the induction of the immune system by pathogen attack and is roughly divided into five types: (1) formation of papilla, (2) hardening of cell wall, (3) hypersensitive response (HR), (4) production of phytoalexins, and (5) produc- 
tion of PR proteins. (1) and (2) are resistance acquisition through the formation of a physical barrier. The generation of reactive oxygen species (ROS) by HR induces another type of defense mechanisms. Phytoalexins and some PR proteins, on the other hand, have antimicrobial activity. All the above-mentioned types of induced resistance are accompanied by changes in the metabolic system and take place in not only infected cells localized acquired resistance (LAR), but also the whole plant systemic acquired resistance (SAR).

These types of defense mechanisms in induced resistance operate by sensing a substance called elicitor on the receptor. The elicitors include abiotic substances, such as heavy metals and synthetic compounds in the form of fungicides, and biotic substances, such as proteins, lipids, oligosaccharides, and antibiotics of biological origin. In fact, elicitors are found in the cell wall of pathogens, and PR proteins, such as chitinase and $\beta-1,3$-glucanase, function indirectly by releasing oligosaccharide elicitors from the cell wall of pathogens $[17,18]$.

\section{Definition and classification of PR proteins}

In this section, we define and classify in detail the PR proteins described above. PR proteins were discovered for the first time in tobacco leaves, indicating the plant's hypersensitive reaction to tobacco mosaic virus (TMV) $[14,19]$. These proteins are found in many plant species [20], including grape.

\subsection{Definition}

PR proteins are proteins encoded but not expressed in host plant in the absence of interaction with a pathogen. They are also defined as proteins generally induced in an infection [21, 22]. PR proteins are also induced under conditions of nonpathogenic origin, such as stress. Examples include cytoplasm separation [23] and high concentrations of plant hormones [24].

\begin{tabular}{llll}
\hline Family & Property & Function/target site & Reference \\
\hline PR-1 & Antifungal & Unknown & {$[31]$} \\
PR-2 & $\beta-1,3-G l u c a n a s e$ & Cell wall $(\beta-1,3$-glucan) & {$[35-39,56]$} \\
PR-3 & Chitinase (types I, II, IV, V, VI, and VII) & Cell wall (chitin) & Cell wall (chitin) \\
PR-4 & Chitinase (types I and II) & Plasma membrane & {$[37,40-42]$} \\
PR-5 & Thaumatin-like & RNA & {$[43-46,57]$} \\
PR-10 & Ribonuclease (like) & Involvement in defense signaling pathway & {$[47-54,58-61]$} \\
PR-14 & Lipid-transfer protein & Production of $\mathrm{H}_{2} \mathrm{O}_{2}$ with & {$[55]$} \\
PR-15 & Oxalate oxidase & Antimicrobial activity & \\
PR-16 & Oxalate oxidase-like protein & & \\
\hline
\end{tabular}

Table 2. Classification of PR proteins in Vitis. 


\subsection{Classification}

PR proteins share many biochemical properties that render them easily distinguishable. They have relatively low molecular weights, are stably extractable at low $\mathrm{pH}[25,26]$, are highly resistant to proteases [27], and have extreme isoelectric points. Most of them are located in the apoplast [28, 29]. In general, acidic PR proteins are located in the apoplast and basic ones, in the vacuole. PR proteins are classified on the basis of amino acid sequences, serological reaction, enzymatic activity, and others. Five groups of PR proteins (PR-1 to PR-5) were initially characterized in tobacco. Currently, PR proteins are categorized into 17 families [30], but not all are found in grape (Table 2). In the next section, the roles and functions of PR proteins in grape (Table 2) are described in detail.

\section{PR protein gene in $V$. vinifera grape}

\subsection{Pathological function}

\subsubsection{PR-1 (unknown)}

Although PR-1 proteins exhibit antifungal activity, their functions remain unclear. $V$. vinifera PR-1 was identified and cloned [31]. However, in grapes, signaling pathway related to PR-1 is remains to be determined. The signaling network of LAR and SAR has been well studied in recent years in Arabidopsis thaliana (Figure 1).

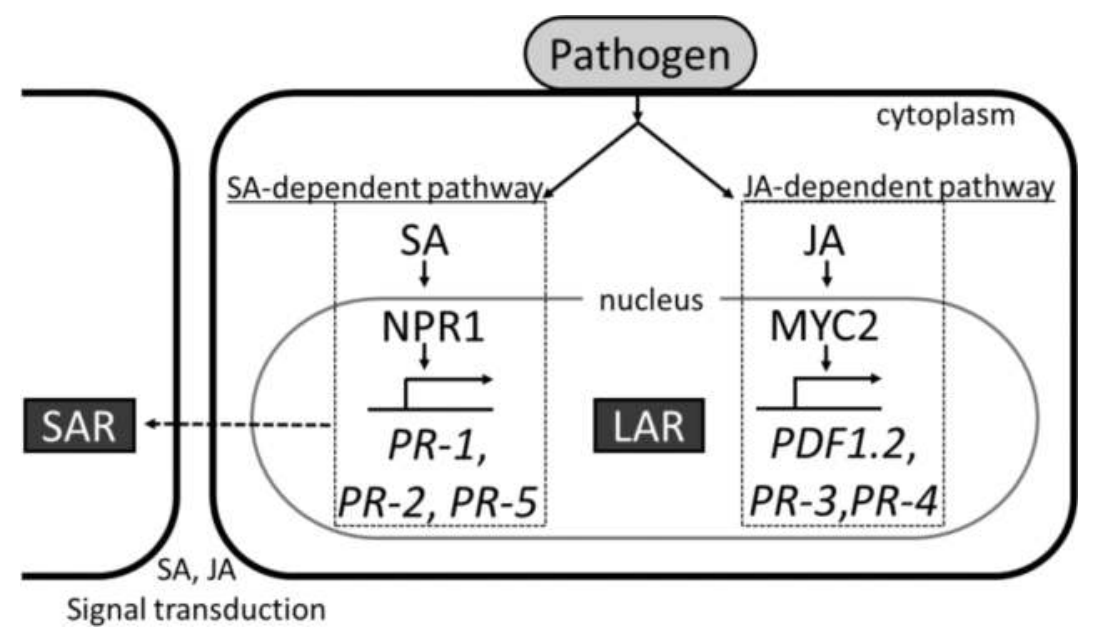

Figure 1. Predicted pathogen-induced signaling pathways leading to LAR and SAR in Arabidopsis thaliana. HR, hypersensitive reaction; SA, salicylic acid; NPR1, NON-EXPRESSER OF PATHOGENESIS-RELATED GENES 1; JA, jasmonic acid; MYC2, transcription factor MYC2; PDF1.2, plant defensin 1.2; LAR, localized acquired resistance; SAR, systemic acquired resistance. 
LAR is induced by pathogen attack. SA and JA act as a second messenger [32]. In response to SA, positive regulator protein non-expresser of pathogenesis-related genes 1 (NPR1) is transported to the nucleus and activate the expression of PR protein genes, including the $P R-1$ [33]. On the other hand, JA dependent pathway is upregulated by MYC2, transcription factor, and induces plant defense-related genes, such as the plant defensin 1.2 (PDF1.2) [34]. As a result, LAR is induced in pathogen-infected cells. Further, when SA and JA signaling are transported to other cells, SA and JA similarly induce the expression of plant defense-related genes through the NPR1 and MYC2. Finally, SAR is expressed in other noninfected cells. Some classes of PR proteins, including PR-1, are known to be expressed in association with SAR.

\subsection{2. $P R-2$ ( $\beta-1,3$-glucanases) and $P R-3$ and -4 (chitinases)}

PR-2 proteins are $\beta$-1,3-glucanases and PR-3 and -4 proteins are chitinases. Because $\beta-1,3-$ glucanases and chitinases were discovered as PR proteins early on, they had been widely studied for their roles in plant defense against pathogens in many species, including grape. They exert antimicrobial activity as a result of their ability to hydrolyze fungal cell wall components. The former hydrolyze $\beta-1,3$-glucan and the latter hydrolyze chitin. The synergistic effects of $\beta-1,3$-glucanases and chitinases inhibit the growth of fungal pathogens [35, 36]. These proteins function indirectly by releasing the elicitor of oligosaccharides from the cell wall of pathogens, thereby inducing various plant defense mechanisms. As shown in Figure 1, the expression of PR-2 gene along with the PR-1, PR-5 gene is dependent on SA [33], expression of PR-3, PR-4 gene depends on the JA in Arabidopsis [32].

Jacobs et al. [37] showed that the hydrolytic activity in grape directly affects the extent of infection by powdery mildew at the pathogen infection site. $\beta-1,3$-Glucanase and chitinase activities were strongly induced in leaves and pre-véraison berries by ethephon treatment. Moreover, PR protein expression was decreased during grape maturation, which explains the increased susceptibility of grape to pathogen attack at the final stage of maturation [38]. Apoplasmic $\beta$-1,3-glucanase gene (VvGHF17) is expressed constitutively in grape leaves, berry pulp, and skin, and VvGHF17-overexpressing Arabidopsis plants exhibited disease resistance to B. cinerea and Colletotrichum higginsianum [39].

\subsubsection{PR-5 (thaumatin-like proteins)}

PR-5 proteins include thaumatin-like proteins and osmotin. The amino acid compositions and the $\mathrm{NH}_{2}$ terminal sequences of thaumatin-like proteins showed that thaumatin-like proteins are actually osmotins, which are known to accumulate in tobacco cells in response to osmotic stress [40]. PR-5 proteins are believed to be involved in enhancing fungal membrane permeability and causing osmotic rupture of fungal plasma membrane [41]. Jayasankar et al. [42] demonstrated in vitro and in vivo that the constitutive expression of $V$. vinifera thaumatin-like protein 1 (VVTL-1) in V. vinifera protected grape from anthrax. Treatment with ethephon, which effects ethylene generation, induced grape PR-5 gene families in leaves and berries [37]. 


\subsubsection{PR-10 (ribonuclease (like))}

PR-10 proteins exhibit ribonuclease (RNase) activity. RNase contributes to plant defense in programmed cell death during HR or acts directly against pathogens [43]. PR-10 gene (VpPR10.2) isolated from Vitis pseudoreticulata exhibited resistance to fungi and had high homology with VvPR10.2 from susceptible V. vinifera cultivar. In contrast to VvPR10.2, VpPR10.2 was induced at high levels in response to P. viticola infection [44]. On the other hand, PR-10 proteins with cytokinin-binding activity were identified in mung bean [45] and moss [46]. Questions persist regarding the roles of PR-10.

\subsubsection{PR-14 (lipid transfer proteins)}

PR-14 proteins are lipid transfer proteins (LTPs). Some LTP-like polypeptides show antifungal or antibacterial activity $[47,48]$. Several isoforms are involved in the plant defense signaling pathway [49-51]. Type I LTP of tobacco binds jasmonic acid (JA), a signaling molecule, and the complex interacts with receptors on the cell membrane [52]. Some grape LTPs bind JA. The external application of the VvLTP4-JA complex to grape plantlets enhanced resistance to $B$. cinerea infection compared to the application of either VvLTP4 or JA alone [53]. Such elicitors as ergosterol triggered VvLTP1 upregulation by WRKY transcription factor and stilbene synthase gene expression in grape plantlets, and enhanced the production of resveratrol (grape phytoalexin) and the resistance to B. cinerea [54].

\subsection{6. $P R-15$ (oxalate oxidases) and PR-16 (oxalate-oxidase-like proteins)}

PR-15 and PR-16 include germins (oxalate oxidases) and germin-like proteins (oxalate-oxidaselike proteins), respectively. Many germin-like proteins exhibit oxalic acid ester oxidase (OXO) or superoxide dismutase (SOD) activity. They are involved in the production of $\mathrm{H}_{2} \mathrm{O}_{2}$ a ROS, which has antimicrobial activity. Seven germin-like protein (GLP) cDNA clones were isolated from $V$. vinifera 'Chardonnay' [55]. V. vinifera germin-like 3 (VvGLP3) is strongly induced by $U$. necator infection. Neither VvGLP1 nor VvGLP7 was induced by $U$. necator, but these were induced by B. cinerea or P. viticola infection.

\subsubsection{Others}

PR-6, PR-7, PR-8, PR-9, PR-11, PR-12, and PR-13 are proteinase inhibitors, endoproteases, chitinases (type III), peroxidases, chitinases (type I), defensins, and thionins, respectively. To the best of our knowledge, these proteins have not yet been detected in grape.

\subsection{Physiological function}

Some PR protein families have physiological functions. For example, PR-2 proteins $(\beta-1,3-$ glucanases) hydrolyze $\beta$-1,3-glucan in fungal cell wall, but because $\beta$-1,3-glucan (called 'callose' in plants), the substrate of $\beta$-1,3-glucanase, is widespread in plants, PR-2 proteins must perform various physiological functions, such as flower formation [56]. Many examples of PR-10 and PR-14 proteins have been reported in grape. The overexpression of grapevine PR-10 gene (Vvpr10) in Saccharomyces cerevisiae conferred salt tolerance in the yeast [57]. Some LTP 
isoforms are involved in somatic embryo development and epidermal layer formation. LTP gene is expressed during zygotic and somatic embryogenesis [58-60]. The overexpression of VvLTP1 gene interferes with somatic embryo development and invalidates the bilateral symmetry of the embryo in grape [61].

\section{Application of PR proteins to pathogen control in V. vinifera grapevine}

Fungicides are used to control fungal diseases. However, their adverse effects on the environment and the appearance of fungi resistant to the fungicides have been reported. Therefore, the development of new plant disease control methods is desired. In recent years, new strategies to increase plant resistance have been examined. Among them, PR-protein-related pathogen control methods are described here.

\subsection{Molecular breeding}

For a long time, researchers and breeders have used conventional breeding methods for the development of disease-resistant cultivars from available resources in genus Vitis. However, conventional breeding methods are hampered by a major problem, namely, hybrid produced by crossing often exhibits undesirable traits from hybrid parent resistant to fungi. In order to remove these traits, backcrossing is performed many times. On the other hand, molecular breeding by a transformation method can use breeding resources other than those from genus Vitis and offers the possibility of improving only the objective trait, such as disease resistance, without modifying other viticulturally desirable traits in the target cultivars.

\begin{tabular}{|c|c|c|c|c|}
\hline Target cultivar & Introduced gene & Gene source & Acquired resistance to & Reference \\
\hline 'Merlot' & Chitinase & Trichoderma & B. cinerea and $U$. necator & [63] \\
\hline \multicolumn{5}{|l|}{ ‘Chardonnay' } \\
\hline ‘Chardonnay' & Chitinase & Trichoderma & B. cinerea and $U$. necator & [65] \\
\hline ‘Thompson Seedless' & Chitinase & Trichoderma & B. cinerea & [64] \\
\hline ‘Neo Muscat’ & Chitinase & Rice & U. necator and Elsinoe ampelina & [66] \\
\hline ‘Pusa Seedless’ & Chitinase & Rice & U. necator & [67] \\
\hline ‘Crimson Seedless' & Chitinase and $\beta$-1,3-glucanase & Wheat & P. viticola & {$[68]$} \\
\hline ‘Thompson Seedless' & TLP (cisgenic) & Chardonnay & U. necator & [70] \\
\hline ‘Seyval blanc' & Chitinase and RIP & Barley & No effect & [69] \\
\hline
\end{tabular}

$\beta-1,3-$ Glucanase (PR-2); chitinase (PR-3 and -4); TLP, thaumatin-like protein (PR-5); RIP, ribosome-inactivating protein.

Table 3. Disease resistance traits introduced into V. vinifera cultivars.

Most commercially valuable $V$. vinifera cultivars are susceptible to pathogens, particularly fungi, as described above. Many studies that have attempted to confer fungal resistance to $V$. vinifera cultivars, including wine grape and table grape, via the transformation technique have 
been reported. The major findings appear in Table 3. The first report of a transformation technique for $V$. vinifera was by Kikkert et al. [62, 63]. The introduction of chitinase from Trichoderma conferred disease resistance to $V$. vinifera cultivars and established a transformation system with embryogenic cultures of $V$. vinifera 'Merlot' and 'Chardonnay' by a biolistic method. Thereafter, examples of the Agrobacterium-mediated transformation method using transgenic chitinase were reported [64-68]. Nookaraju and Agrawal [68] also reported that the introduction of both $\beta$-1,3-glucanase (PR-2) and chitinase in transgenic plants increased resistance to downy mildew. Transgenic plants that displayed no resistance in field tests have also been reported [69]. The increase of disease resistance by chitinase introduction has been reported in other plants as well. Chitin is the main component of the cell wall in major pathogens, U. necator, B. cinerea, and P. viticola. As higher plants do not contain chitin, chitinase does not affect growth and development in plants. Therefore, this control strategy using chitinase is considered to be very effective.

Recently, PR proteins aside from the above have been used and strategies other than transgenic approaches have been attempted. V. vinifera 'Crimson Seedless' expressing cisgenic thaumatinlike proteins (TLP, PR-5) from $V$. vinifera 'Chardonnay' displayed resistance to powdery mildew [70]. Although the transformation method is adopted, cisgenic plants are produced by using a gene derived from a closely related species originally present in nature as genetic resources. Although cisgenic plants fall under regulations for transgenic plants, discussions are underway as to whether cisgenic plants should be excluded from the regulations in the EU and the US [71].

\subsection{New chemical control method using elicitors}

Transgenic grapevines are forbidden in French vineyards. Aziz et al. [72] proposed an alternative strategy for controlling pathogens, which is the activation of plant defense mechanism by elicitors. Defense reactions elicited by laminarin increase PR protein (chitinase and $\beta-1,3$-glucanase) activities and confer resistance to $B$. cinerea and $P$. viticola growth [72]. It is considered that the induction of natural plant defense mechanisms by elicitors is an attractive and powerful method compared with chemical fungicides [73]. Indeed, a number of positive results against downy and powdery mildew and gray mold have been reported in laboratories and greenhouses [74]. However, little research has been carried out in vineyards. In addition, results comparable to those obtained in laboratories have not been generated and its effect seems to be weaker than that of the conventional fungicide method. This variability is likely due to environmental, plant, pathogen, and external conditions. To quote Delaunois et al. [74], 'Additional research needs to be pursued to fully understand defense stimulation under vineyard conditions.'

\section{Conclusions}

Knowledge of the roles and functions of genes encoding PR proteins in grape has been accumulated from previous studies of other plants, such as tobacco, and used in the develop- 
ment of new methods for controlling pathogens in grape. However, questions remain, such as the presence of PR proteins of other classes in grape and the regulation PR protein genes involved in the plant defense mechanism. Elucidating the answers to these questions at the molecular level will help further our understanding of PR proteins in V. vinifera and create possibilities to improve grape quality and yield by efficiently preventing pathogen growth in the future.

\section{Acknowledgements}

Special thanks go to Ms. Kayo Arita, Mr. Masachika Mikami, and Mr. Yoshinao Aoki of the University of Yamanashi for their assistance.

\section{Author details}

Shinichi Enoki and Shunji Suzuki*

*Address all correspondence to: suzukis@yamanashi.ac.jp

Laboratory of Fruit Genetic Engineering, The Institute of Enology and Viticulture, University of Yamanashi, Yamanashi, Japan

\section{References}

[1] Staudt, G. (1997). Evaluation of resistance to grapevine powdery mildew (Uncinula necator [Schw.] Burr., anamorph Oidium tuckeri Berk.) in accessions of Vitis species. VITIS, 36(3), 151.

[2] Doster, M. A., \& Schnathorst, W. C. (1985). Comparative susceptibility of various grapevine cultivars to the powdery mildew fungus Uncinula necator. American Journal of Enology and Viticulture, 36(2), 101-104.

[3] Mullins, M. G., Bouquet, A., \& Williams, L. E. (1992). Biology of the grapevine. Cambridge University Press, Cambridge.

[4] Latorre, B. A., Elfar, K., \& Ferrada, E. E. (2015). Gray mold caused by Botrytis cinerea limits grape production in Chile. Ciencia e investigación agraria: revista latinoamericana de ciencias de la agricultura, 42(3), 316-330.

[5] Clark, J. S. C., \& Spencer-Phillips, P. T. N. 2000. Downy mildew. In: Lederberg, J., Alexander, M., Bloom, B. R., Hopwood, D., Hull, R., Iglewski, B. H., Laskin, A. I., Oliver, 
S. G., Schaechter, M., \& Summers, W. C. (Eds.), The Encyclopedia of Micro-biology, vol. 2. Academic Press, San Diego, USA, pp. 117e129.

[6] Boso, S., Alonso-Villaverde, V., Gago, P., Santiago, J. L., \& Martínez, M. C. (2014). Susceptibility to downy mildew (Plasmopara viticola) of different Vitis varieties. Crop Protection, 63, 26-35.

[7] Delye, C., Laigret, F., \& Corio-Costet, M. F. (1997). A mutation in the 14 alpha-demethylase gene of Uncinula necator that correlates with resistance to a sterol biosynthesis inhibitor. Applied and Environmental Microbiology, 63(8), 2966-2970.

[8] Chen, W. J., Delmotte, F., Cervera, S. R., Douence, L., Greif, C., \& Corio-Costet, M. F. (2007). At least two origins of fungicide resistance in grapevine downy mildew populations. Applied and Environmental Microbiology, 73(16), 5162-5172.

[9] Ishii, H., Fraaije, B. A., Sugiyama, T., Noguchi, K., Nishimura, K., Takeda, T., Amano, T., \& Hollomon, D. W. (2001). Occurrence and molecular characterization of strobilurin resistance in cucumber powdery mildew and downy mildew. Phytopathology, 91(12), $1166-1171$.

[10] Mizuta, H., \& Yasui, H. (2012). Protective function of silicon deposition in Saccharina japonica sporophytes (Phaeophyceae). Journal of applied phycology, 24(5), 11771182.

[11] Mabekoje, O. O., Bello, O. O., \& Egberongbe, H. O. (2013). Antimicrobial efficacy of ocimum gratissimum andvernonia amygdalina on gastrointestinal bacteria. Canadian Journal of pure and applied sciences, 7(2), 2341.

[12] Aist, J. R., Structural responses as resistance mechanisms, in The Dynamics of Host Defense, Bailey, J. A., Ed., Academic Press, New York, 1983, 33.

[13] Brisson, L. F., Tenhaken, R., \& Lamb, C. (1994). Function of oxidative cross-linking of cell wall structural proteins in plant disease resistance. The Plant Cell, 6(12), 1703-1712.

[14] Van Loon, L. C., \& Van Kammen, A. (1970). Polyacrylamide disc electrophoresis of the soluble leaf proteins from Nicotiana tabacum var.'Samsun'and 'Samsun NN': II. Changes in protein constitution after infection with tobacco mosaic virus. Virology, 40(2), 199 211.

[15] Dixon, R. A. (1986). The phytoalexin response: elicitation, signalling and control of host gene expression. Biological Reviews, 61(3), 239-291.

[16] Linthorst, H. J., \& Van Loon, L. C. (1991). Pathogenesis-related proteins of plants. Critical reviews in plant sciences, 10(2), 123-150.

[17] Keen, N. T., \& Yoshikawa, M. (1983). $\beta$-1, 3-Endoglucanase from soybean releases elicitor-active carbohydrates from fungus cell walls. Plant Physiology, 71(3), 460-465.

[18] Yamaguchi, T., Yamada, A., Hong, N., Ogawa, T., Ishii, T., \& Shibuya, N. (2000). Differences in the recognition of glucan elicitor signals between rice and soybean: 
$\beta$-glucan fragments from the rice blast disease fungus Pyricularia oryzae that elicit phytoalexin biosynthesis in suspension-cultured rice cells. Plant Cell, 12(5), 817826.

[19] Gianinazzi, S., Martin, C., \& Vallee, J. (1970). Hypersensibilite aux virus, temperature et proteines solubles chez le Nicotiana xanthi n. c: apparition de nouvelles macromolecules lors de la repression de la synthese virale. Academic Press Paris CR Ser D, 270, 2382-2386.

[20] Van Loon, L. C. (1985). Pathogenesis-related proteins. Plant Molecular Biology, 4(2), 111-116.

[21] Antoniw, J. F., \& White, R. F. (1980). The effects of aspirin and polyacrylic acid on soluble leaf proteins and resistance to virus infection in five cultivars of tobacco. Journal of Phytopathology, 98(4), 331-341.

[22] Van Loon, L. C., Pierpoint, W. S., Boller, T. H., \& Conejero, V. (1994). Recommendations for naming plant pathogenesis-related proteins. Plant Molecular Biology Reporter, 12(3), 245-264.

[23] Wagih, E. E., \& Coutts, R. H. (1981). Similarities in the soluble protein profiles of leaf tissue following either a hypersensitive reaction to virus infection or plasmolysis. Plant Science Letters, 21(1), 61-69.

[24] Antoniw, J. F., Kueh, J. S. H., Walkey, D. G. A., \& White, R. F. (1981). The presence of pathogenesis-related proteins in callus of Xanthi-nc Tobacco. Journal of Phytopathology, 101(2), 179-184.

[25] Van Loon, L. C. (1976). Specific soluble leaf proteins in virus-infected tobacco plants are not normal constituents. Journal of General Virology, 30(3), 375-379.

[26] Gianinazzi, S., Pratt, H. M., Shewry, P. R., \& Miflin, B. J. (1977). Partial purification and preliminary characterization of soluble leaf proteins specific to virus infected tobacco plants. Journal of General Virology, 34(2), 345-351.

[27] Pierpoint, W. S., Robinson, N. P., \& Leason, M. B. (1981). The pathogenesisrelated proteins of tobacco: their induction by viruses in intact plants and their induction by chemicals in detached leaves. Physiological Plant Pathology, 19(1), 85-IN29.

[28] Parent, J. G., \& Asselin, A. (1984). Detection of pathogenesis-related proteins (PR or $b$ ) and of other proteins in the intercellular fluid of hypersensitive plants infected with tobacco mosaic virus. Canadian Journal of Botany, 62(3), 564-569.

[29] Carr, J. P., Dixon, D. C., Nikolau, B. J., Voelkerding, K. V., \& Klessig, D. F. (1987). Synthesis and localization of pathogenesis-related proteins in tobacco. Molecular and Cellular Biology, 7(4), 1580-1583. 
[30] Van Loon, L. C., Rep, M., \& Pieterse, C. M. J. (2006). Significance of inducible defenserelated proteins in infected plants. Annual Review of Phytopathology, 44, 135-162.

[31] Bertsch, C., Joly, D., \& Walter, B. (2003). Sequence of a putative Vitis vinifera PR-1. Vitis, 42(2), 103-104.

[32] Thomma, B. P., Eggermont, K., Penninckx, I. A., Mauch-Mani, B., Vogelsang, R., Cammue, B. P., \& Broekaert, W. F. (1998). Separate jasmonate-dependent and salicylatedependent defense-response pathways in Arabidopsis are essential for resistance to distinct microbial pathogens. Proceedings of the National Academy of Sciences, 95(25), 15107-15111.

[33] Uknes, S., Mauch-Mani, B., Moyer, M., Potter, S., Williams, S., Dincher, S., Chandler, D., Slusarenko, A., \& Ryals, J. (1992). Acquired resistance in Arabidopsis. The Plant Cell, $4(6), 645-656$.

[34] Dombrecht, B., Xue, G. P., Sprague, S. J., Kirkegaard, J. A., Ross, J. J., Reid, J. B., Fit, G. P., Sewelam, N., Schenk, P. M., Manners, J. M., \& Kazan, K. (2007). MYC2 differentially modulates diverse jasmonate-dependent functions in Arabidopsis. The Plant Cell, 19(7), 2225-2245.

[35] Mauch, F., Mauch-Mani, B., \& Boller, T. (1988). Antifungal hydrolases in pea tissue II. Inhibition of fungal growth by combinations of chitinase and $\beta-1,3$-glucanase. Plant Physiology, 88(3), 936-942.

[36] Jongedijk, E., Tigelaar, H., Van Roekel, J. S., Bres-Vloemans, S. A., Dekker, I., van den Elzen, P. J., Cornelissen, B. J., \& Melchers, L. S. (1995). Synergistic activity of chitinases and $\beta$-1,3-glucanases enhances fungal resistance in transgenic tomato plants. Euphytica, 85(1-3), 173-180.

[37] Jacobs, A. K., Dry, I. B., \& Robinson, S. P. (1999). Induction of different pathogenesisrelated cDNAs in grapevine infected with powdery mildew and treated with ethephon. Plant Pathology, 48(3), 325-336.

[38] Monteiro, S., Piçarra-Pereira, M. A., Loureiro, V. B., Teixeira, A. R., \& Ferreira, R. B. (2007). The diversity of pathogenesis-related proteins decreases during grape maturation. Phytochemistry, 68(4), 416-425.

[39] Fujimori, N., Enoki, S., Suzuki, A., Naznin, H. A., Shimizu, M., \& Suzuki, S. (2016). Grape apoplasmic $\beta$-1,3-glucanase confers fungal disease resistance in Arabidopsis. Scientia Horticulturae, 200, 105-110.

[40] Stintzi, A., Heitz, T., Kauffmann, S., Legrand, M., \& Fritig, B. (1991). Identification of a basic pathogenesis-related, thaumatin-like protein of virus-infected tobacco as osmotin. Physiological and Molecular Plant Pathology, 38(2), 137-146.

[41] Roberts, W. J., \& Selitrennikoff, C. P. (1990). Zeamatin, an antifungal protein from maize with membrane-permeabilizing activity. Journal of General Microbiology, 136(9), 17711778. 
[42] Jayasankar, S., Li, Z., \& Gray, D. J. (2003). Constitutive expression of Vitis vinifera thaumatin-like protein after in vitro selection and its role in anthracnose resistance. Functional Plant Biology, 30(11), 1105-1115.

[43] Liu, J. J., \& Ekramoddoullah, A. K. (2006). The family 10 of plant pathogenesis-related proteins: their structure, regulation, and function in response to biotic and abiotic stresses. Physiological and Molecular Plant Pathology, 68(1), 3-13.

[44] He, M., Xu, Y., Cao, J., Zhu, Z., Jiao, Y., Wang, Y., Xin Guan, X., Yang, Y., Xu, W., \& Fu, Z. (2013). Subcellular localization and functional analyses of a PR10 protein gene from Vitis pseudoreticulata in response to Plasmopara viticola infection. Protoplasma, 250(1), 129-140.

[45] Fujimoto, Y., Nagata, R., Fukasawa, H., Yano, K., \& Azuma, M. others. (1998). Purification and cDNA cloning of cytokinin-specific binding protein from mung bean (Vigna radiata). European Journal of Biochemistry, 258, 794-802.

[46] Gonneau, M., Pagant, S., Brun, F., \& Laloue, M. (2001). Photoaffinity labelling with the cytokinin agonist azido-CPPU of a $34 \mathrm{kDa}$ peptide of the intracellular pathogenesisrelated protein family in the moss Physcomitrella patens. Plant Molecular Biology, 46(5), 539-548.

[47] Cammue, B. P. A., Thevissen, K., Hendriks, M., Eggermont, K., Goderis, I. J., Proost, P., Van Damme, J., Osborn, R. W., Guerbette, F., Kader, J. C., \& Broekaert, W. F. (1995). A potent antimicrobial protein from onion seeds showing sequence homology to plant lipid transfer proteins. Plant Physiology, 109(2), 445-455.

[48] Terras, F. R., Schoofs, H. M., De Bolle, M. F., Van Leuven, F., Rees, S. B., Vanderleyden, J., Cammue, B. P., \& Broekaert, W. F. (1992). Analysis of two novel classes of plant antifungal proteins from radish (Raphanus sativus L.) seeds. Journal of Biological Chemistry, 267(22), 15301-15309.

[49] Maldonado, A. M., Doerner, P., Dixon, R. A., Lamb, C. J., \& Cameron, R. K. (2002). A putative lipid transfer protein involved in systemic resistance signalling in Arabidopsis. Nature, 419(6905), 399-403.

[50] Blein, J. P., Coutos-Thévenot, P., Marion, D., \& Ponchet, M. (2002). From elicitins to lipidtransfer proteins: a new insight in cell signalling involved in plant defense mechanisms. Trends in Plant Science, 7(7), 293-296.

[51] Grant, M., \& Lamb, C. (2006). Systemic immunity. Current Opinion in Plant Biology, 9(4), 414-420.

[52] Buhot, N., Gomès, E., Milat, M. L., Ponchet, M., Marion, D., Lequeu, J., Delrot, S., Thévenot, P. C., \& Blein, J. P. (2004). Modulation of the biological activity of a tobacco LTP1 by lipid complexation. Molecular Biology of the Cell, 15(11), 5047-5052.

[53] Girault, T., François, J., Rogniaux, H., Pascal, S., Delrot, S., Coutos-Thévenot, P., \& Gomès, E. (2008). Exogenous application of a lipid transfer protein-jasmonic acid 
complex induces protection of grapevine towards infection by Botrytis cinerea. Plant Physiology and Biochemistry, 46(2), 140-149.

[54] Laquitaine, L., Gomès, E., François, J., Marchive, C., Pascal, S., Hamdi, S., Atanassova, R., Delrot, S., \& Coutos-Thévenot, P. (2006). Molecular basis of ergosterol-induced protection of grape against Botrytis cinerea: induction of type I LTP promoter activity, WRKY, and stilbene synthase gene expression. Molecular Plant-Microbe Interactions, 19(10), 1103-1112.

[55] Godfrey, D., Able, A. J., \& Dry, I. B. (2007). Induction of a grapevine germin-like protein (VvGLP3) gene is closely linked to the site of Erysiphe necator infection: a possible role in defense? Molecular Plant-Microbe Interactions, 20(9), 1112-1125.

[56] Akiyama, T., Pillai, M. A., \& Sentoku, N. (2004). Cloning, characterization and expression of OsGLN2, a rice endo-1,3- $\beta$-glucanase gene regulated developmentally in flowers and hormonally in germinating seeds. Planta, 220(1), 129-139.

[57] Jellouli, N., Jouira, H. B., Daldoul, S., Chenennaoui, S., Ghorbel, A., Salem, A. B., \& Gargouri, A. (2010). Proteomic and transcriptomic analysis of grapevine PR10 expression during salt stress and functional characterization in yeast. Plant Molecular Biology Reporter, 28(1), 1-8.

[58] Vroemen, C. W., Langeveld, S., Mayer, U., Ripper, G., Jurgens, G., Van Kammen, A., \& De Vries, S. C. (1996). Pattern formation in the Arabidopsis embryo revealed by position-specific lipid transfer protein gene expression. Plant Cell, 8(5), 783-791.

[59] Coutos-Thevenot, P., Jouenne, T., Maes, O., Guerbette, F., Grosbois, M., Caer, J. P., Boulay, M., Deloire, A., Kader, J. C., \& Guern, J. (1993). Four 9-kDa proteins excreted by somatic embryos of grapevine are isoforms of lipid-transfer proteins. European Journal of Biochemistry, 217(3), 885-889.

[60] Sterk, P., Booij, H., Schellekens, G. A., Van Kammen, A., \& De Vries, S. C. (1991). Cellspecific expression of the carrot EP2 lipid transfer protein gene. Plant Cell, 3(9), 907921.

[61] François, J., Lallemand, M., Fleurat-Lessard, P., Laquitaine, L., Delrot, S., CoutosThévenot, P., \& Gomès, E. (2008). Overexpression of the VvLTP1 gene interferes with somatic embryo development in grapevine. Functional Plant Biology, 35(5), 394-402.

[62] Kikkert, J. R., Ali, G. S., Striem, M. J., Martens, M., Wallace, P. G., Molino, L., \& Reisch, B. I. (1996). Genetic engineering of grapevine (Vitis sp.) for enhancement of disease resistance. In III International Symposium on In Vitro Culture and Horticultural Breeding, 447, 273-280.

[63] Kikkert, J. R., Ali, G. S., Wallace, P. G., Reisch, B., \& Reustle, G. M. (1998). Expression of a fungal chitinase in Vitis vinifera L. 'Merlot' and 'Chardonnay' plants produced by biolistic transformation. In VII International Symposium on Grapevine Genetics and Breeding, 528, 299-306. 
[64] Hinrichsen, P., Reyes, M. A., Castro, A., Araya, S., Garnier, M., Prieto, H., Reyes, F., Muñoz, C., Dell'Orto, P., \& Moynihan, M. R. (2005). Genetic transformation of grapevines with Trichoderma harzianum and antimicrobial peptide genes for improvement of fungal tolerance. In VII International Symposium on Grapevine Physiology and Biotechnology, 689, 469-474.

[65] Reisch, B., Kikkert, J., Vidal, J., Ali, G., \& Gadoury, D. (2002). Genetic transformation of Vitis vinifera to improve disease resistance. In VIII International Conference on Grape Genetics and Breeding, 603, 303-308.

[66] Yamamoto, T., Iketani, H., Ieki, H., Nishizawa, Y., Notsuka, K., Hibi, T., Hayashi, T., \& Matsuta, N. (2000). Transgenic grapevine plants expressing a rice chitinase with enhanced resistance to fungal pathogens. Plant Cell Reports, 19(7), 639-646.

[67] Nirala, N. K., Das, D. K., Srivastava, P. S., Sopory, S. K., \& Upadhyaya, K. C. (2010). Expression of a rice chitinase gene enhances antifungal potential in transgenic grapevine (Vitis vinifera L.). VITIS, 49(4), 181.

[68] Nookaraju, A., \& Agrawal, D. C. (2012). Enhanced tolerance of transgenic grapevines expressing chitinase and $\beta$-1,3-glucanase genes to downy mildew. Plant Cell, Tissue and Organ Culture (PCTOC), 111(1), 15-28.

[69] Bornhoff, B. A., Harst, M., Zyprian, E., \& Töpfer, R. (2005). Transgenic plants of Vitis vinifera cv. Seyval blanc. Plant Cell Reports, 24(7), 433-438.

[70] Dhekney, S. A., Li, Z. T., \& Gray, D. J. (2011). Grapevines engineered to express cisgenic Vitis vinifera thaumatin-like protein exhibit fungal disease resistance. In Vitro Cellular \& Developmental Biology-Plant, 47(4), 458-466.

[71] Holme, I. B., Wendt, T., \& Holm, P. B. (2013). Intragenesis and cisgenesis as alternatives to transgenic crop development. Plant Biotechnology Journal, 11(4), 395-407.

[72] Aziz, A., Poinssot, B., Daire, X., Adrian, M., Bézier, A., Lambert, B., Joubert, J. M., \& Pugin, A. (2003). Laminarin elicits defense responses in grapevine and induces protection against Botrytis cinerea and Plasmopara viticola. Molecular Plant-Microbe Interactions, 16(12), 1118-1128.

[73] Klarzynski, O., \& Fritig, B. (2001). [Stimulation of plant natural defenses]. Comptes rendus de l'Academie des sciences. Series III, Sciences de la vie, 324(10), 953-963.

[74] Delaunois, B., Farace, G., Jeandet, P., Clément, C., Baillieul, F., Dorey, S., \& Cordelier, S. (2014). Elicitors as alternative strategy to pesticides in grapevine? Current knowledge on their mode of action from controlled conditions to vineyard. Environmental Science and Pollution Research, 21(7), 4837-4846. 